\title{
The impact of Syrian refugees on Jordan: A framework for analysis
}

\author{
Wa'ed Alshoubaki \\ Department of Public Administration, University of Jordan \\ Jordan \\ w.alshoubaki@ju.edu.jo \\ Michael Harris \\ Department of Public Administration, Tennessee State University \\ USA \\ mharris50@Tnstate.edu
}

Abstract. The civil war in Syria has caused a mass influx of Syrian refugees into other countries throughout the region and beyond. Jordan has received a large share of Syrian refugees, currently totaling to the alarming number of $1.2 \mathrm{mln}$ people. Addressing the need of Syrian refugees has drained the resources of Jordanian government and has had its substantial impact on Jordanian society overall. In an effort to better understand the humanitarian, political, economic, sociocultural and environmental challenges to Jordan and its government, this study has developed a comprehensive analytical framework. The comprehensive analytical

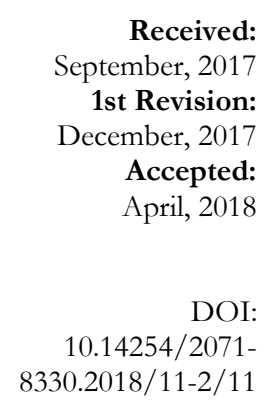

Received: September, 2017 1st Revision: December, 2017 Accepted: April, 2018

DOI: $8330.2018 / 11-2 / 11$ framework has been developed based on the system thinking approach and the systematic review of gray literature and peer-reviewed articles. This framework provides a better capacity to discover the potential consequences of a massive refugee influx and covers the vital factors based on the realistic criteria regarding the burden of refugees on the formulation of policies. The analytical framework is applied to Jordan as the receiving state since the influx of Syrian refugees into Jordan in 2011 to 2015 and it potentially could be used as a comparative analytical tool for other receiving states.

Keywords: analytical framework, humanitarian crisis, Jordan, receiving state, Syrian refugees

JEL Classification: F22, J69

\section{INTRODUCTION}

After the Arab Spring revolutions broke out in late 2010, violence erupted in Syria in March 2011 leading to a fierce civil war. After five years of civil war that resulted in the death of over 200,000 people 
and the global dispersal of more than 12 million refugees who fled their homes, 4 million Syrians have sought refuge in Arab countries and Turkey (Ministry of Planning and International Cooperation [MOPIC], 2015). Jordan received 1.2 million Syrians during this crisis. Of these Syrian refugees, $84 \%$ lived outside refugee camps, specifically in Amman and the northern governorates, and 16\% settled inside refugee camps (MOPIC, 2015). Jordan has opened its borders to let Syrian refugees enter the state and live in safe conditions according to the humanitarian need (Nasser \& Symansky, 2014). However, the presence of so many Syrian refugees has affected Jordan's economy, security, and quality of life (Nasser \& Symansky, 2014). Jordan's small size and lack of natural and economic resources have exacerbated the living conditions for both refugees and the hosting community. According to the United Nations' refugee agency the United Nations High Commissioner for Refugees (UNHCR, 2015), Jordan has been influenced by the civil war in the Syria Arab Republic; the influx of Syrian refugees into Jordan has created a considerable burden on national and local systems and infrastructures.

Based on the Jordanian government's estimate, the direct cost of Syrian refugees for the government since the beginning of the crisis in 2011 to 2016 was about $\$ 4.2$ billion (Sharp, 2016). Therefore, the Jordanians have revealed concerns about their open border policy; they have also been cautioned regarding the competition over scarce resources and limited public budgeting (Sharp, 2016). It is a fact that communities agreeably absorb influxes of foreign people from different backgrounds, but when the number of immigrants becomes unusually large, which may lead to regulatory outcomes, local population strongly reacts to the risk of losing power and supremacy (Allport, 1954).

From a more practical standpoint, this study examines the impact of Syrian refugees, which is one of the most complicated and dynamic humanitarian issues in the world today (United Nations Office for Coordination of Humanitarian Affairs [UNOCHA], 2016). The civil war in Syria has externally displaced 4.8 million refugees since the beginning of 2016 (UNOCHA, 2016). Furthermore, the ramifications of this war extend all over the region and beyond. For example, Syrian refugees have spread throughout the Middle East, Europe, and North America. Jordan has received a substantial number of refugees, and according to recent reports, the government of Jordan is becoming more economically and financially vulnerable because of the sudden increase in population and thus higher demand for public services. Many studies have explored the impact of the Syrian refugees' influx on receiving states based on the existing theories and specific sets of explanatory variables. However, this study was conducted as a response to the needs of the World Bank and the Refugee Studies Centre at Oxford University for new methods to assess the impact of refugees on host countries. These methods should assist policymakers and humanitarian organizations by providing "appropriate and easy-to-use assessment tools" (Zetter, 2015,p. 50) to analyze the economic consequences of providing humanitarian aid to the displaced people. Therefore, this study addresses the impact of Syrian refugees on Jordan as a receiving state through the development of a comprehensive analytical framework for the acceptance of refugees.

\section{LITERATURE REVIEW}

The presence of refugees poses several types of impacts based on the condition of the received states and the relations between refugees and host communities, including political, economic, sociocultural, and environmental impacts. Meyers (1997) asserted that environmental effect is associated with social effect and health effect, which are also accompanied with cultural and economic impacts. In other words, the various effects of refugees on host countries are inseparable.

The following review of the refugee literature is based on the analytic framework for studying refugees' impact on receiving states. the four aspects of the analytical framework-political, economic, sociocultural, 
and environmental-represent the contextual factors of refugee crises in receiving states, and they correspond with the overall parameter of government intervention to deal with the catastrophe.

\subsection{Political impact}

A number of studies suggest that the influx of refugees evokes a strained political relationship between receiving and sending countries. The inflow of refugees shapes several types of conflicts on received states, including conflict of refugees within the host government because refugees tend to arrange groups fighting against their state of origin or even against their host states, as well as conflict of refugees within host communities due to the rivalry relation between refugees and host communities, especially when refugees receive better and free services compared to citizens. In addition, civil wars in neighboring countries extend the tension to receiving countries, especially when camps are close to the borders of two countries (Kirui \& Mwaruvie, 2012).

Salehyan (2008) argues that the influx of refugees develops conflict between the sending state and hosting state and creates the need for a militarized interstate dispute between them. He assumes that host countries start militarizing action to protect their borders against sending states and to avert further inflows of refugees. Moreover, sending countries encroach the host country's borders to strike fugitives, dissidents, and ethnic groups who flee due to the civil war and to penalize the host country for refugees' reception because most refugees are active combatants who have participated in the violence. Camps can therefore be considered a place to recruit rebels to launch militarized action.

Several studies have examined the relationship between the mass influx of refugees and the likelihood of civil war outbreaks in host countries. For example, Salehyan and Gleditsch (2006) pointed out that the flow of refugees from neighboring countries increases the probability of a spread of conflict. Particularly, refugees spread civil war to the bordering countries due to the interaction of rebel social networks with social actors in hosting states through their social, economic, and cultural bonds. In addition, refugees impose negative externality, which represents the economic burden of refugees on host countries and leads the host communities to revolt against current conditions. Scholars argue that there are multiple reasons for conflict diffusion and the clustering of civil war. In essence, the causes of civil war and the actors who are involved in the conflict spread beyond the national borders (Gleditsch, 2007). Civil war that occurs due to ethnic cleansing and the removal of an ethnic group leads to transnational ethnic groups, causing the same ethnic groups in the receiving states to support their own race and join them in violence to defend their own issues (Davis \& Moore, 1998; Saideman 2001). According to Beissinger (2002), due to a "demonstration effect," conflict diffuses from one country to another because people change their beliefs and attitudes regarding their government's efficiency and demand government reformation. For instance, the Arab spring was a revolutionary wave sparked by Tunisia in December 2010, which then spread to Egypt, Libya, Yemen, and Syria as citizens expressed their dissatisfaction with their government's performance and the prevalence of corruption in some Arab League countries. Historically, the influx of refugees from neighboring countries has resulted in the spread of political problems and conflict.

Salehyan and Gleditsch (2006) explained the connection between the presence of refugees and ignition of civil war in host countries. The influx of refugees brings fighters and ideologies that enable them to establish their political structure and challenge host states through the expansion of their social network. To illustrate, the Palestine Liberation Organization and Palestinian refugees in Jordan in 1970 collaborated to challenge the Jordanian government especially when the Popular Front of Liberation of Palestine (PFLP) hijacked three foreign aircrafts; for this reason, Jordan's army attacked Palestinian refugee camps to counter violent cells. The Palestine Liberation Organization retaliated and killed various soldiers and citizens (Salehyan \& Gleditsch, 2006). Refugees not only unite with people of the same ethnicity and ideologies in 
host countries, but they also provide resources and support them to encourage national resistance. Finally, host communities refuse the existence of refugees due to their social and economic burdens, and they revolt against refugees; this movement is popular in developing countries and is known as the sons of the soil movement (Salehyan \& Gleditsch, 2006).

Whitaker's (2002) study investigates the role of refugees in conflict diffusion in host countries. She claims that the flow of refugees might cause spread of conflict in host countries because they modify the country's demography and the balance of power, competing with citizens for existing resources. However, the effect of refugees' presence is varied based on three factors:

- The legitimacy of the existing regime.

- The degree of using of ethnic groups in political activity.

- The leaders' strategies and tactics to sustain power.

The political context of receiving countries plays an important role in refugees' settlement. For instance, in Congo, the Mobutu regime was known as a dictatorship and a corrupted regime that caused economic problems. Society protested for political reform, and Mobutu dealt with the crisis by threatening the protesters. The Congolese people were frustrated with Mobutu's efforts to curb the demand for political reform and realized the impossibility of a nonviolent transition. Therefore, protesters and opposition groups recruited poor and unemployed people, including Rwandan refugees who became prominent members, to participate in the violence. Conversely, in Tanzania, the economic reform was fruitful, and the political regime was democratic. Tanzanians were thus satisfied with government performance and granted it more legitimacy. Therefore, mechanisms of dealing with Rwandan refugees were much easier, and more refugees were more peaceful (Whitaker, 2002).

The second factor is the use of ethnic groups in political plans because using refugees as ethnic tools may exacerbate the conflict in receiving countries. For example, Congo tried to politicize the ethnic group to regain its legitimacy in the international community, but using refugees was not a lifeline for the extractive system. Unlike Congo, Tanzania did not use refugees as a political tool, and Nyerere asserted at the importance of the Tanzanian identity, using Swahili as a national language and deliberately excluding refugees from politics (Whitaker, 2002).

Whitaker (2002) argued that the way that Congo's regime used refugees to prevent political reform magnified the existing divisions to destroy revolutionaries, leading to more intense tensions and violence. In contrast, Tanzania excluded Rwandan refugees from their political tactics and took all procedures to prevent an outbreak of violence in their terrain.

Weiner (1993) claims that the "conflict creates refugees, but refugees can also create conflict" (p. 106). Armed refugees become a political threat against host countries because they will be capable of intervening in host countries and affect their stability and security. For example, armed Palestinian refugees in Lebanon promoted instability and civil war in 1975, which led to armed confrontation between the Palestinian Liberation Organization and the Lebanese army. Moreover, sometimes refugees politically split against host countries in favor of a hostile state. For example, the collaboration between Palestinian refugees in Kuwait and Iraq's invaders in 1990 caused the Kuwaiti government to fire around 400,000 Palestinians in high-level positions after the end of the war with Iraq. This demonstrates the extent to which refugees can become a threat to receiving states

\subsection{Economic impact}

The presence of refugees in host countries has caused a significant debate over its positive and negative economic consequences and the conditions under which refugees become a burden or a potential benefit to the economy of the host country. Maystadt and Verwimp (2014) assessed the long-term effect of refugees' 
exodus in Kagera in northwestern Tanzania. The Kagera region is considered the lowliest per capita in Tanzania. The ramifications of refugees were mixed, and their presence yielded positive and negative consequences. In essence, Kagera witnessed an acute increase in prices due to the increased demand from refugees and humanitarian organizations' staff. Refugees were exchanging their received allowances from the United Nations and other nonprofit organizations, which caused increased prices of some goods. Refugees led to the reduction of wages because they willingly worked for low wages. However, skilled people had a substantial increase in their wages. Private industry boomed for both refugees and host communities. Finally, Kagera's infrastructure, health care, and sanitation improved due to projects being completed such as roads, airfields, and telecommunications. The positive impact of refugees in Kagera region has been attributed to the camps' spatial concentration of economic activities generating positive spillover through the sharing of inputs and the utilizing of international assistance.

Several scholars maintain that refugees are not only a political threat to host communities, but they are also an economic burden. Neighboring countries travail the spillover effects of civil war, which has an inverse effect on their economic development (De Groot, 2010). Salehyan (2008) argues that civil war in neighboring countries causes a negative spillover. He points out that refugees shape multiple types of negative externalities. In spite of international aid to refugees, received countries sustain more cost of supporting and caring for refugees. This burden is magnified when receiving countries are poor and underdeveloped because refugees need human aid and public services. Refugees compete with citizens' job opportunities and resources. Refugees shape demographic externality because they may affect ethnic balance. In addition, the inflow of refugees increases the probability of conflict in received states. Refugees can cause health problems to host communities due to sanitation problems and infectious diseases. For example, Baez (2011) analyzed the impact of influx of Burundian and Rwandan refugees to Western Tanzania in 1993 and 1994 and its effect on Tanzanian children. He employs Tanzania Demographic Health Surveys (TDHS) to assess the short-term effect of the massive influx of refugees. The results reveal that the influx of refugees significantly exacerbates the nutritional status of children in host communities. Moreover, west Tanzania suffers from health problems, such as malaria, AIDS, and other communicable diseases, and the flow of refugees worsens the problem and contributes to the spread of diseases.

Murdoch and Sandler (2004) empirically tested the impact of a civil war on sending and receiving countries. They claimed that ramifications of civil war on a state entail loss of human capital, reduced local investment, redirection of foreign investment, and the destruction of infrastructure. Neighboring countries have not been spared the negative effect of civil war. Civil war hinders economic growth in neighboring countries, disrupts trade and the importing of resources, and results in high costs to provide humanitarian aid to refugees. Economically, they found that "civil wars have significant, but modest, negative influences on the steady state level of GDP per capita, both at home and in neighbors" (p. 92).

International Monetary Fund and World Bank (1999) assessed the economic impact of the Kosovo crisis on the six most affected European countries. The report includes the following receiving countries: Albania, Bosnia-Herzegovina, Bulgaria, Croatia, Macedonia, and Romania.

The report found that a major influence of the Kosovo crisis was the massive influx of refugees associated with a large segment of the direct cost that was allocated from host countries' budget to support refugees and provide food, shelter and clothing (Deppler \& Kincaid, 1999). The steep exodus of refugees leads to turbulent conditions, especially in the demographic and social structure. Received countries exert substantial efforts to maintain law and order, and they are also confronted with economic challenges due to the need to provide humanitarian assistance to refugees, such as the port congestion in Albania. The accumulation of these conditions causes a weakened ability to govern (Deppler \& Kincaid, 1999).

Moreover, closing trade routes and transport networks due to closing the border with Serbia and Montenegro led to the loss of Macedonia, which exported $66 \%$ of its production to Serbia and Montenegro. 
In the same vein, Bosnia and Herzegovina lost an important market in Yugoslavia. Bulgaria and Romania had problems in the destruction of their storage facilities in Bosnia and Herzegovina; furthermore, using transit trade led to an extended period of trade and an increase in transportation costs for Bulgaria and Romania (Deppler \& Kincaid, 1999).

The unstable conditions and influx of refugees reduced consumers' and investors' trust, resulting in the loss of foreign investment, loss of tourism trade in Croatia and Bulgaria, loss in local business, and the high borrowing cost in the international capital market (Deppler \& Kincaid, 1999).

International Monetary Fund and World Bank (1999) asserted that the inflow of refugees abated a structural reform in different countries because of obstacles of administrative capacity, making the compromise for reform challenging. For example, privatization projects deteriorated. Albania also found problems in tax collection.

The report concluded that the economic cost of the refugee influx was higher than estimated, and even though the conflict was resolved, the trade market was damaged due to the closing of trade routes and the need for more time to deport refugees added more costs (International Monetary Fund and World Bank, 1999). Finally, in spite of the international support of the Kosovo crisis, the report detailed significant negative impact on the growth of the state.

In the case of Jordan, the country received many refugees in different eras, including Palestinian refugees in 1948, Iraqi refugees in 1990 and 2003, and Syrian refugees in 2011. Several studies were conducted to assess the effect of the turbulent condition in the Middle East on the economic growth of Jordan. Saif and Debartolo (2007) investigated the impact of the Iraqi refugee influx after the Iraq invasion in 2003 and how they impacted economic growth. They found that, during the Iraqi refugee influx, the country witnessed an increase in food prices, petroleum, and property; however, they underestimated the role of Iraqi refugees on the rise of inflation. When they split up inflation by governorates, the inflation rate of Amman, where most of the Iraqi refugees resided, was less than the inflation rate across the country. In a recent study about the impact of refugees in Jordan economics, Lozi (2013) evaluated the impact of refugees on the Jordan economy by the major macroeconomic indicators, including unemployment rate, foreign direct investment, and food pricing. He indicated that the increase of inflation in years 2010-2012 was caused by food prices increasing; the massive influx of refugees led to an increase in the demand of food, thus increasing food importation by $11 \%$. Before the influx of Syrian refugees, Jordan was trying to control food prices, but after the steep influx of refugees, Jordan was unable to control prices, and subsidies decreased. Moreover, the inflow of Syrian refugees, in addition to the Iraqi refugees, put greater pressure on Jordan's public services and budget. An increase in the demand on public services caused an increase in government expenditure. Regarding the high unemployment rate in Jordan, Jordanians argued that Syrian refugees were working illegally without work permits. Lozi asserted that the turbulent condition of the region worsened the economic conditions in Jordan, cutting back investment and tourism. Finally, the majority of Jordanians believe that Syrian refugees have political and social impacts on Jordan.

\subsection{Sociocultural impact}

The influx of refugees have a potential effect on the social and cultural structure of host communities and may generate social tension between refugees and host communities due to several social barriers, such as racism, xenophobia, and language difficulties. Several studies assessed refugees' social impact on received states. Gomez and Christensen (2011) claimed that refugees impact host societies through the distortion of ethnicity balance and social competition over resources and public services. Basically, the sociocultural effect of refugees happens as a result of their presence because, even in the most hostile communities, refugees may dissent with another group that is affiliated with the same group that forced them to seek refuge. For 
example, the conflict between Kosovo-Albanian refugees and Albanians and Serbs in Macedonia was based on ethnicity (Gomez \& Christensen, 2011; Pini, 2008). However, sociocultural tension is diminished and becomes more peaceful when refugees and host communities share the same culture, religion, and language because they are homogenous, and the opportunity for social integration is high (UNHCR, 2007). For example, the extreme inflow of Pashtun Afghan refugees to the North West Frontier Province in Pakistan was peaceful and stable because the North West Frontier Province was dominated by people of the Pashtun culture who treated Afghan refugees as relatives and friends. Betts (2009) asserted that a strained social relationship among local citizens and refugees occurs due to inequalities among them, and due to local citizens considering refugees as competitors for scarce resources and public services. However, such tensions can be alleviated through international support for both host communities and refugees. To illustrate, the influx of refugees in Tanzania positively affected host communities because a Special Program for Refugees Affected Area (SPRRA) was allocated as a public project that benefited all people with facilitation farming, road construction, and airfield (Gomez \& Christensen, 2011; Whitaker, 2002).

From another perspective, Gomez and Christensen (2011) demonstrated that the conditions of refugees per se lead them to social conflict because the refugee community experienced gender-based dominance, which negatively influences household relations due to the increase of women generating more income than men, causing problems especially in the patriarchal societies of developing countries that lack job opportunities for men (Gomez \& Christensen, 2011; Women's Refugee Commission, 2009). The evidence from Somali refugees in Sanna in Yemen, male Somalians did not find jobs, which made females to access the labor market through work as housekeepers and provide income to their households, a dependence situation leading to social disorder and local violence (Gomez \& Christensen, 2010; Morris, 2010). It is worth shedding light on the previously reviewed article about the types of refugees' externalities for Salehyan and Gleditsch (2006) when they argued that demographic externalities shape threats on host communities and make them more vulnerable to strife. In essence, refugees alter the ethnic balance of received states, and conflict may also be sparked by nativists who are worried about their local population structure. In addition, sometimes an alliance between nationals and refugees of the same race and ethnicity generates conflict in the state. Salehyan (2008) briefly described the major causes of demographic externalities, First, host communities show extreme antagonism because they consider refugees a threat to their culture. Second, the ethnic strain occurs due to the accumulation of ethnic network ties among minorities in the host community. Brown (1996) stated "the sudden influx of refugees can aggregate ethnic problems and further complicate the picture by changing the domestic balance of power" (p. 576).

\subsection{Environmental impact}

The steep influx of refugees into host communities increases demand on the environment and puts great pressure on its natural resources. Several studies have examined the effect of refugees' presence on received states' environmental problems such as desertification, deforestation, water scarcity, and famine. Gomez and Christensen (2011) reported that the receiving of refugees is accompanied with negative effects on natural resources, ecosystem, and hovel growth. According to the researchers, the influx of refugees entails several damaging environmental practices such as cutting trees for the purposes of settlement, construction, and firewood. The major effects of refugees on the environment of host communities are forest depletion, exhaustion of water ground resources, land deterioration, water contamination, and the spread of diseases. They maintained that the deleterious effect of refugees varies based on the settlement style; for instance, in the case of Kenya, camp settlements caused land degradation, while the integration of refugees with the national populations of Tanzania and Zambia reduced the negative effect of refugees' 
inflow on the environment. The influx of refugees in underdeveloped countries and the untenable population growth increase the competition for received states' resources.

Jacobsen (1997) described the environmental effect of the massive influx of refugees on host natural resources because it causes a sharp increase in population, deforestation, increased water consumption, and pollution. He also explained settlement types and their environmental effect on host countries. Selfsettlement clarifies the effect of unofficial assistance from citizens by providing loaned houses and food in increasing the population density. Organized settlement is in the form of camps and relief assistance centers. The camp settlement's effect on the environment starts with the initial inflow of refugees and the construction of camps that lead to cutting trees and clearing lands; furthermore, the concentration and immobility of refugees in one area increase the strain of natural resources and may cause depletion to the existing resources. Agricultural settlement aims to enhance refugees' self-sufficiency and reduce the host government's burden; however, this type of settlement encompasses population growth and inadequate land for farming, and restricted movement leads to the overburdening of resources and increased pressure on the environment. Jacobsen contended that refugees shape a daily environmental threat through their activities and conditions because controlling diseases and infectious animals and the use of pesticides cause the accumulation of toxic chemicals in soils and then to humans.

Refugees' movement creates conflict for political, ethnic, and social reasons; moreover, environmental conflict shapes additional reasons to trigger conflict between refugees and host communities. Martin (2005) studied the direct and indirect causes of conflict associated with the presence of refugees. He asserted that environmental insufficiency is considered an indirect cause of conflict because the inflow of refugees strains natural resources and leads to social and environmental tension. The UNHCR report in 1996 categorized the environmental impact of refugees on host communities as the degradation of natural resources, depletion of resources, and health problems, which trigger economic and social problems. In essence, the sudden growth of the population increases the demand on local resources and increases the poverty among refugees and national citizens (Martin, 2005).

Berry (2008) studied the impact of Burundian and Rwandan refugees in Tanzania's environmental conditions, especially the degradation and overuse of water. She found that there was escalation in environmental problems, including water usage, natural resource depletion, and illegal land cleaning and harvesting. However, the results were attributed to both the population growth of Tanzanians and the presence of refugees. Also, NGOs alleviated the threat of refugees' over-use of environmental resources through environmental education, providing wood-saving stoves, and water source management.

\section{A comprehensive analytical framework for refugees' adoption in receiving state}

There is a lack of a theoretical background and a need for an appropriate assessment tool that can answer questions regarding the effect of refugees' presence on a receiving state. Therefore, a detailed sketch of the possible impact of the acceptance of refugees on a receiving state has been prepared in virtue of scientific principles and the previous experiences of other states that received refugees. Specifically, this framework intends to answer how the Jordanian government and Jordanian host communities have been impacted by the influx of Syrian refugees. Therefore, this study constructed a comprehensive analytical framework to determine the impact of refugees' presence on a receiving state, particularly the impact of Syrian refugees on Jordan and Jordanian society. An analytical framework was developed based on major contextual factors-namely, political, economic, sociocultural, and environmental factors-to provide evidence concerning the impact of Syrian refugees on the Jordanian government. In essence, a poor understanding of the contextual factors may influence the ability of analysts to make judgments regarding the issues in a given case (Edwards\& Steins, 1998). According to Edward and Steins (1998), contextual factors involve "dynamic forces such as social, economic, cultural, political, technological and institutional 
environments that are beyond the control of community" (p. 366).This section addresses the analytical framework's foundation, components, and methods and includes a discussion.

\section{Foundation}

A lack of a specific theory to assess the impact of the influx of refugees on a receiving state led to the construction of a comprehensive analytical framework of refugees adoption (CAFRA) that enabled us to build a platform to organize the structural indicators that are embedded in governmental actions and the reactions of host communities to the presence of refugees. Overall, the creation and use of an analytical framework help a researcher to determine the components of the phenomenon that is being studied, and it categorizes the elements in the research arena in a manner that involves several theories in the analysis and discussion (Ostrom, 2009). Although an analytical framework involves implicit theories from an ontological basis, it aims to logically categorize the elements of a study to reduce its complexity (Stanley, 2012). Unlike a theory, which is a reflection of reality, an analytical framework clarifies and justifies the issues for study (Stanley, 2012). However, both theories and analytical frameworks can be applied from various perspectives and to various research problems (Stanley, 2012).

Practically, a framework enables policymakers to assemble information from previous empirical studies and past experiences to offer a diagnostic explanation of a phenomenon (McGinnis \& Ostrom, 2014). Technically, a framework is "theory-neutral so that competing hypotheses from alternative theoretical perspectives could be evaluated on a common basis" (McGinnis \& Ostrom, 2014, p. 30).

Ostrom (2005) articulates the differences between a framework and a model. A model begins with a postulate of a hypothesis based on limited variables to predict the relationship between the dependent and independent variables in a particular context, whereas a framework builds upon groups of concepts and terms that can be used to diagnose and explain a phenomenon (Ostrom, 2005). In short, a framework works as a podium on which a model and a theory are composed (Ostrom, 2009).

In this paper, this analytical framework is considered a new paradigmatic trend that has been created based on the systems thinking the approach to analyze the impact of Syrian refugees' inflow on Jordan as a receiving state. In essence, systems thinking allows a researcher to develop a profound awareness of the underlying realities because this thinking approach promotes addressing a phenomenon as a whole, not only a particular part, and it emphasizes the interactions and connections of a problem context (Richmond, 1993).

Scholars argue that the systems thinking approach are used when a case is considered an unprecedented phenomenon because it needs be studied through a comprehensive approach, not a reductionist approach. The systems thinking approach addresses interconnections, dynamics, and interactions with the environment, and it sustains an entire perspective to be acknowledged and considered even when a study emphasizes a particular component of the overall framework (Darnhofer, Gibbon, \& Dedieu, 2012).

For this reason, the CAFRA has been created to analyze the impact of Syrian refugees on Jordan as a receiving state. This framework is constructed based on the major contextual factors that organize and reflect the potential impact of refugees' presence on receiving states and host communities according to the current conditions of the receiving state and the characteristics of the refugees and host communities.

This framework involves multiple academic disciplines and includes major indicators that enable a researcher to address the impact of refugees' presence in receiving states. The interdisciplinary nature of the CAFRA assures the connection of multiple types of knowledge, concepts, standards, and measures of the phenomenon from different academic paths. For example, the CAFRA includes four main tiersspecifically, the political, economic, sociocultural, and environmental tiers-and demonstrates the importance of interdisciplinary features for a complete explanation and analysis. Moreover, the analytical framework of the acceptance of refugees is flexible because it can be applied to analyze the impact of the surge of refugees whenever and wherever they flee from conflict. Accordingly, this framework is not limited 
to Jordan and Syrian refugees but can be used to analyze the impact of refugees in any country that hosts refugees or that addresses refugee crisis.

A practical view of this analysis is that refugees interact within the community strata and interaction atmosphere, which causes congestion and stress that lead to several types of pressure. The presence of refugees imposes different types of impacts on the receiving state and host communities that can be summarized through political drivers, economic drivers, sociocultural drivers, and environmental drivers. All these drivers are cumulated as a node that creates pressure on the structure, or fabric, of the receiving state; then, this node tears the fabric and creates holes, destabilizing state structure.

The analytical framework of the acceptance of refugees has been built based on factual information that has been collected from the gray literature, the Jordanian governmental database, official newspapers, the UNHCR, the United Nations Development Programme (UNDP), and a relief web database. The data are categorized and discussed based on the political, economic, sociocultural, and environmental indicators that correspond to each analytical tier.

\section{Components}

The analytical framework of the acceptance of refugees comprises four major tiers that reflect the impact of refugees' presence on a receiving state based on contextual factors. The major tiers are as follows.

Political impact. The political impact tier incorporates the consequences of the flow of refugees on the receiving state such as the internal conflict between host communities, political negative externalities, infusion of conflict from the sending to the receiving state due to the geopolitical relationships between them, rebel mobilization, and political affiliation of host communities and refugees.

Economic impact. The economic impact tier involves the ramifications of refugees' settlement on the economy of a receiving state based on macroeconomic and fiscal indicators. For instance, this tier includes the effect of refugees on the labor market, negative externalities, trade, banking, tourism, public spending, lost income, and customs fees.

Sociocultural impact. The social complications of refugees' presence in host communities have been subsumed under two categories: first, cultural gaps and ethnicity changes and second, social disorder, population density and the complexity of refugees as a lost generation.

Environmental impact. The environmental impact tier involves the consequences of refugees' influx on the ecology of a receiving state such as water consumption, land degradation, forest depletion, and infections.

These tiers of the CAFRA for the acceptance of refugees in a receiving state vary based on the conditions of the receiving state before the crisis. For example, the political impact appears in countries neighboring the conflict and in the shared borders areas where refugees and internally displaced people settle. Moreover, the possibility of political turbulence increases when the receiving state and refugee camps include hidden radical groups. The negative economic impact arises in high unemployment rates, poverty, a nonindustrial state, high public debt, and a fragile economy. The socio-cultural impact emerges when a receiving state has a different culture, language, and customs; in this circumstance, the language barrier, religion, stereotypes, and exclusion problems overemphasize the ramifications of the presence of refugees. In countries that suffer from water shortages, lack of energy resources and severe climate make the receiving state more vulnerable to the impact of this presence. 
Table 1

The Major Contextual Factors of Analysis and Their Potential Effect Based on Receiving State Features

\begin{tabular}{|c|c|c|}
\hline Contextual Tiers & High Impact & Low Impact \\
\hline Political tier & $\begin{array}{c}\text { A shared border and the presence } \\
\text { of radical groups }\end{array}$ & $\begin{array}{c}\text { No shared border and no radical } \\
\text { groups present }\end{array}$ \\
\hline Economic tier & $\begin{array}{c}\text { High unemployment rate, no } \\
\text { industrial state, low GDP, and high } \\
\text { public debt }\end{array}$ & $\begin{array}{c}\text { Industrial state, low unemployment } \\
\text { rate, economic boom state, and } \\
\text { high GDP }\end{array}$ \\
\hline Sociocultural tier & $\begin{array}{c}\text { Dissimilar religion, language, } \\
\text { ethnicity or ancestry }\end{array}$ & $\begin{array}{c}\text { Shared religion, language, ancestry, } \\
\text { ethnicity, and religious doctrine }\end{array}$ \\
\hline Environmental tier & $\begin{array}{c}\text { Water shortages, desertification, } \\
\text { and a lack of natural resources and } \\
\text { renewable energy }\end{array}$ & $\begin{array}{c}\text { Rich water resources, natural } \\
\text { resources, and renewable energy } \\
\text { sources }\end{array}$ \\
\hline
\end{tabular}

\section{METHODOLOGY}

The comprehensive analytical framework in this paper has been developed based on systems thinking approach. The systems thinking approach pertains to the overall analysis to discover the components of a complex system and the interactive relationships among different levels of this system (Carey et al., 2015). Systems thinking comprises the analysis and synthesis perspectives that make the idiosyncratic feature of this approach a scientific method (Barton \&Haslett, 2007). The development of this analytical framework emanates from the idea that an analytical framework is a synthesizing and guiding tool to integrate information from multiple data sources (Lichtenstein, Yetley, \& Lau, 2009).

This analytical framework was developed based on the following steps.

- Step one: Sketch the framework based on the contextual factors that serve as the drivers of the overall impact of the acceptance of refugees on a receiving state. Political, economic, sociocultural, and environmental factors were defined to construct the analytical framework.

- Step two: Identify the design of the framework through systems thinking. A systematic review of articles, gray literature, and official news agencies was conducted to assess the relevant studies. The included studies were divided into two sections. The first section includes articles and reports that relate to the previous experiences of the receiving state with the acceptance of refugees the first lens of a comprehensive analytical framework of refugee adoption construction to facilitate the comprehension and evaluation of the construction process. The second section includes the articles, governmental reports, humanitarian agency studies, and official news regarding the influx of Syrian refugees into Jordan.

- Step three: Analyze and synthesize the content of the articles, reports, and news. Seventytwo sources were used in the analysis and synthesis process. In essence, the analysis process entails the dividing of the components of a complex phenomenon to facilitate understanding (Ritchey, 1991). The synthesis process is the combination of all the components of a phenomenon to shape a comprehensible form of a case that is subject to a study (Ritchey, 1991). Ritchey (1991) asserted that analysis and synthesis as scientific methods are closely associated and accompany one another. To illustrate, synthesizing is performed based on the previous analysis, and analyzing requires a subsequent synthesis to confirm or correct the analysis results (Ritchey, 1991). 
- Search strategy: Systematic reviews of refugee studies and refugee reports were utilized to assemble the scientific evidence and integrate the analytical facts to assess the impact of Syrian refugees on Jordan and hosting communities. A systematic review provides an exhaustive method to synthesize and evaluate a scientific source (Lichtenstein et al., 2009). This search strategy "minimizes potential reporting bias through comprehensive and reproducible searches using clearly defined and described selections and reporting protocols" (Lichtenstein et al., 2009, p. 3). Major databases such as ProQuest, the United Nations refugee agency's database, the Jordan MOPIC database, the Central Bank of Jordan database, and official news agencies were employed. The search terms were refugee adoption effect, the political impact of refugees' presence, the economic impact of refugees' presence, the sociocultural impact of refugees' presence, and environmental impact of refugees' presence. Peer-reviewed articles were used for 1999-2015, governmental reports and humanitarian organization reports were used for 2013-2015, and official news reports were assembled for 2012-2015. The used sources were categorized based on an integrative approach to a systematic review. This integrative approach of a systematic review involves defining and identifying categories and concepts prior to piloting the literature search (Dixon-Wood, Agarwal, \& Jones, 2005). The categorization process was conducted based on the four contextual factors of the political, economic, sociocultural, and environmental impact. The exclusion criteria included news from untrusted and unpopular news agencies, news published in the Arabic language, articles that did not describe the burden of refugees on a receiving state, and articles that study the impact of immigrants on a receiving state.

\section{RESULTS AND DISCUSSION}

Political tier. The surge of Syrian refugees imposed a political challenge that the Jordanian government has shouldered to maintain its stability and security and to protect refugees. The geopolitics of Jordan and the long Jordan-Syria border of approximately 235 miles have caused an influx of Syrian refugees into Jordan and have caused Jordan to lead military actions to address the ramifications of the civil war in Syria. This tier represents the political factors that should be considered when assessing the impact of refugees' exodus to the receiving state.

Sending/receiving conflict threat. hosting of Syrian refugees in Jordan has instigated political tension between the Syrian government-Al Assad-and the Jordanian government. The first confrontation between the two troops was in 2012 at the Jordan-Syria border when the Syrian military followed the Syrian people who attempted to cross the border and take refuge in Jordan (RT News, 2012). As the influx of Syrian refugees has continued, tension and poor bilateral relations between the two countries has persisted. The deterioration of diplomatic relations has led to the expulsion of the Syrian ambassador, Bahjat Suleiman, due to his offensive position on Jordan through his personal attacks in addition to ongoing attacks on Jordan through the media and social media (Abuqudairi, 2014). The Jordanian government is working to protect its border from Al Assad's troops, as the sending state attempted to chase fleeing combatants and protesters. For example, the Jordanian Air Force struck a military convoy that attempted to infiltrate the Jordan border. The Jordanian government accused Syrian troops of this penetration operation and then later denied this accusation (Arab News, 2014).

External radicalism threat. The anarchy and disorder in Syria, poor living conditions, and influx of Syrian refugees have led to the spillover of radicalism and conflict in different directions. Scholars assert that poverty, unemployment, and poor quality of life make refugees and internally displaced people more likely to join radical and terrorist groups (Haider, 2014; Lischer, 2003). To illustrate, Jordan found itself 
compelled to lead military action against radicalism and to be an active part of the anti-ISIS coalition to protect its borders and to maintain Jordan's security (Aljazeera, 2015). Jordan has financed opposition groups in southern Syria to secure its border and to avert the further influx of refugees (Aljazeera, 2015). However, the ascending threat of the Islamic state in Jordan is alarming due to the direct confrontation with ISIS at the borders and the failure to attack ISIS inside Jordan (Schenker, 2017). Jordan intensified airstrikes and military operations against ISIS, especially after a Jordanian Air Force pilot, Muath Alkasasbeh, was captured and burned to death by ISIS in January 2015 (BBC, 2015).

Alongside the Jordan-Syria border clashes, penetration trials have become a semi-routine part of the border patrol. Three car bombings have occurred that have targeted the border areas and have caused death and injury to civilians and combatants. The most prominent bombings were the suicide bombing in June 2016, which killed seven people from civil defense and the public security department and injured 14 people (Sharp, 2017), and second, the bloody bombing inside the Rukban refugee camp, which killed 11 Syrian refugees (Aljazeera, 2017).

Internal radicalism threat.Because of the poor economic conditions, demographic changes and ideological variations that have been gradually generated by the presence of Syrian refugees, Jordanians, and other nationalities have joined radical groups. The radical groups make Jordan more vulnerable to terrorist attacks. Jordan has suffered several terrorist attacks. One terrorist attack occurred in June 2016, when a terrorist entered a general intelligence directorate building in a Baqqa Palestinian refugee camp and killed five officers (Schenker, 2017). At the end of the same year, in southern Jordan, Jordanian jihadists who had returned from fighting in Syria killed civilians, security forces, and foreigners and had plans to attack targets on New Year's Eve (Schenker, 2017).

Criminal threat.The camps and borders near conflicts and disorder are more exposed to illegal acts; therefore, Jordanian border patrol addresses many border violations and crimes such as smuggling, penetration, and drug trafficking. These practices are common in refugee camps and the border areas of conflicts. Evidently, two men were slain while trafficking 2.4 million Captagon pills and 2,600 small-sized bags of marijuana (Jordan Times, 2014). Recently, three intruders were killed while smuggling drugs (Jordan Times, 2017).

Political negative externalities. The influx of Syrian refugees and radicalism gave Jordan the necessity of a militarized interstate dispute to address both the security challenge and to provide humanitarian assistance to refugees. The presence of Syrian refugees in Jordan has caused competition over limited resources and job opportunities increased prices and a deterioration in the quality of public services (MercyCorps, 2013). This economic burden of refugees can be called the negative externalities of refugees' inflow (Salehyan \& Gleditsch, 2006). In fact, the economic burden of refugees on host communities leads citizens to protest and creates tension between refugees and the government. Jordanians protested in Amman and in northern Jordan against the worsening of Jordanian living conditions due to the influx of Syria refugees. For instance, Jordanians in Mafraq (North Jordan) protested against the presence of refugees in their city and their competition over housing and job opportunities by constructing tents that were labeled "Camp of displaced Jordanians" (MercyCrops, 2013, p. 9). Jordanians were resentful of being evicted from their homes, and they cannot bear the increase in rent prices from $50 \mathrm{JD}$ per month to $300 \mathrm{JD}$ per month (MercyCorps, 2013). Tensions are escalating between Jordanians as a host community and Syrian refugees because of the decline of the Jordanian quality of life and increases in the daily friction between Syrians and Jordanians (Luck, 2013).

Refugee networking threat. By prudently examining the composition of refugees' structures and network interactions, it can be concluded that refugees have political influence within their camps and begin to manipulate politics outside their camps. In addition to civilians, camps include fighters, veterans, military retirees, and tribal and religious influencers who have the power to incite activities inside camps; this is 
called the rebel mobilization concept. In this context, at the Za'atri camp in Jordan, there was vandalism inside camps, and refugees burned tents, caravans, and vehicles and attacked a police station. They protested against poor living conditions and the arrest of two refugees who tried to illegally abscond from the camps (BBC, 2014).

Street-leader threats. Syrian refugee camps in Jordan contain an alarming anomaly that is the streetleader effect. Street leaders are "powerful individuals and organized gangs [that] have imposed their will on sections of the camp, diverting assistance and engaging in criminal activities" (UNHCR, 2013c, p. 4). These street leaders run criminal practices, and they use their power to exploit aid only for their constituents (Clarke, 2016). Some refugees are indignant of these leaders and consider them to be opportunists whose only aim is to gain power and use it for their own benefit (Clarke, 2016); the UNHCR denied their authority and does not empower them to interfere in camp affairs (Hackl, 2013). However, street leaders have an important political role inside the camps because they organize demonstrations and boycotts; they consider themselves wise and politically strong, and they gain power because they were rebel leaders in their country, previous sheikhs ${ }^{1}$, or were early refugees (Hackl, 2013). The street-leader effect creates an additional threat to Jordanian stability and could be considered a warning of a refugee-warrior threat because they have a strong network, can communicate with the devastated group to diffuse conflicts in Jordan and can militarize refugees and camps. Refugee warriors are former fighters who settle in refugee camps to recruit combatants to regain power to re-attack the sending state or to destabilize the receiving state (Adleman, 1998).

In brief, the brutal civil war in Syria, the exodus of Syrian refugees in record numbers to Jordan, the spread of turmoil in Syria and its ramifications on neighboring countries has triggered political reactions and political cautions in Jordan to maintain stability and security through the militarized interstate dispute, coalition affiliation and tight security procedures. However, the political impact of Syrian refugees has not yet manifested because the number of Syrian refugees, in addition to the previous refugees in Jordan and their relations and networking, must be considered, especially if the historical profile of the refugees in Jordan and the state in exile attitude are analyzed. Population growth alone does not cause violence but rather specific types of demographic changes or group growth cause turbulence and political conflicts (Goldstone, 2002). Moreover, refugees have political demands, and they seek to engage in the political life of the receiving state, especially after long periods of displacement (Haider, 2014). Consequently, within time, the political exclusion of Syrian refugees will shape a new drive to demand more power, to confront the Jordan government and to spread riots.

Economic tier. The broader experience of the refugee influx on the receiving state indicates that the presence of refugees may have a positive impact on the receiving state's microeconomic and labor market in some cases. However, an assessment of the macroeconomics of the receiving state and public finance factors articulate the degree of economic and fiscal strains of hosting refugees. Therefore, this tier analyzes the impact of Syrian refugees and the Syrian crisis on Jordan's macroeconomics, public finances, and labor force.

Public spending. The steep influx of Syrian refugees has caused the Jordanian government additional costs to respond to the crisis due to a sharp increase in the demands for public services and infrastructure. Jordan's total public expenditures have been increased by the presence of refugees, particularly in regions that have received more refugees. Furthermore, the current public expenditure has increased at the expense of investment spending, and that is like putting a spoke in Jordan's development wheel. Jordanian public spending exceeds public revenue despite the levying of additional taxes on Jordanians. For example, compared with taxes before the Syrian refugee influx, Jordanian taxpayers endured a $42 \%$ increase in taxes

${ }^{1}$ A sheik is an Arab leader, particularly the head of a tribe, family, or village (sheikhs, n.d.). 
after the Syrian refugee influx (Jordan Central Bank, 2017). This finding leads this analysis to the free ridership problem as an economic and social dilemma that occurs when a group of people uses resources and services without paying the cost, which results in an insufficient provision of goods and services (Baumol, 1952). A parallel point of view is that the refugees, as newcomers, are benefiting from public goods and services without paying the cost, which burdens the government that is responsible for providing nonrival and non-excludable goods. Evidently, Syrian refugees in Jordan have been using public goods and services free-of-charge, while the Jordanian government and citizens have been paying the price in the form of economic, political, and social challenges (Francis, 2015). Economists suggest government procedures to lessen the negative consequences of the free rider phenomenon with the issuing of regulations to establish standards for the consumption of public goods and resources (Griffiths \& Kickul, 2013). Additionally, the government uses compulsory participation by levying taxes to reduce the provision costs of public goods (Kickul \& Lyons, 2012). However, these solutions are not feasible in the case of refugees' presence because refugees are newcomers and their presence in the country is relatively temporary; for instance, Jordan refers to Syrian refugees as guests to emphasize their short-term presence (Achilli, 2015). Therefore, the Jordanian government cannot levy taxes on Syrian refugees; however, Jordanian citizens bear the additional tax burdens that address the demand for public goods and services to alleviate refugees' free ridership.

Public debt. Jordan suffered from poor economic conditions before the outbreak of civil war in Syria and the influx of Syrian refugees into the country; this fragile economy makes Jordan more vulnerable to the impact of an extreme influx of refugees, the sudden growth in the population, and the increased demand for public services (Luck, 2016). The Jordanian response to the cost of the Syrian refugee crisis was so severe that Jordan's public debt increased from $\$ 18.9$ billion in 2011 to $\$ 35.2$ billion in 2016 (Luck, 2016). Moreover, Jordan's public deficit reached $\$ 1.8$ billion, including the budget deficit and water and electric subsidies (Luck, 2016). As previously argued, the presence of Syrian refugees combined with a lack of refugee burden sharing has caused Jordan to adopt a new debt strategy that depends on external borrowing (Fanek, 2016). In fact, Jordan's external debt rose 100\% in 2015 (Fanek, 2016). The reliance on Jordan's external debt exposes high economic risks and may emerge as a financial crisis, especially when the debt is dominated by foreign currency (Fanek, 2016). Figure 1 illustrates the growth of Jordanian public debt after the Syrian refugee crisis by comparing the Jordanian government debt to its Gross domestic product (GDP).

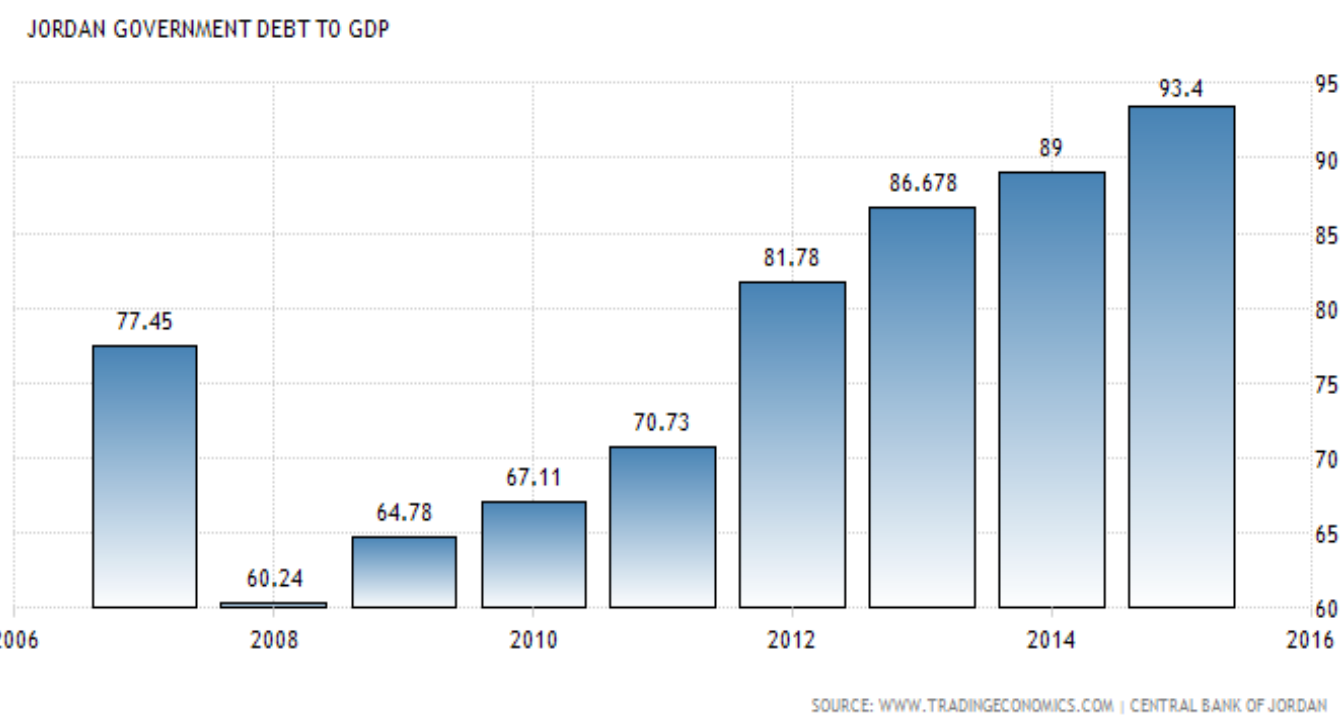

Figure 1. Jordan government debt to GDP 2007-2015

Source: Reprinted from TradingEconomics (2017) 
Trade balance. The vicious conflict in Syria and absence of security have led Jordan to lose its main trade route that connected Jordan with Turkish, Lebanese, and European markets (MOPIC, 2013). Therefore, Jordan has resorted to using an alternative route that is more expensive and that takes longer, which increases prices and customs fees (MOPIC, 2013). Closing the trade route with Syria has negatively affected Jordanian food security because $70 \%$ of Jordan's imported food passes through the Jaber border crossing (Taha, 2015). Moreover, Jordan has lost its primary agricultural market in Syria; for instance, at the beginning of the crisis, agricultural exports to Syria declined approximately $25 \%$, and agricultural imports declined approximately 30\% (MOPIC, 2013). These reductions become more pronounced after the conflict was intensified and a closed border policy was declared. The declining Jordanian trade balance negatively affects Jordan's balance of payment, and consequently, Jordan's economic growth and foreign investment policy have been adversely impacted.

Foreign direct investment. The ongoing turbulent conditions in the Middle East and the spillover effect of Syrian conflicts raise investors' concerns and fears. Compared to other Levant countries and Egypt, Jordan maintains economic stability in terms of investments (MOPIC, 2013). Because Syrian refugees include investors and owners who moved their capital and economic activities to Jordan, the Jordan Investment Board has stated that Syrian investments in Jordan were JD 42 million and JD 49 million in 2012 and 2013, respectively (as cited in MOPIC, 2013). As shown in Figure 2, the overall foreign investment in Jordan decreased at the peak of the Syrian crisis, but it slightly improved at the midpoint of the crisis. Generally, although Jordan's foreign investment has fluctuated, it has been harmed less than other economic factors.

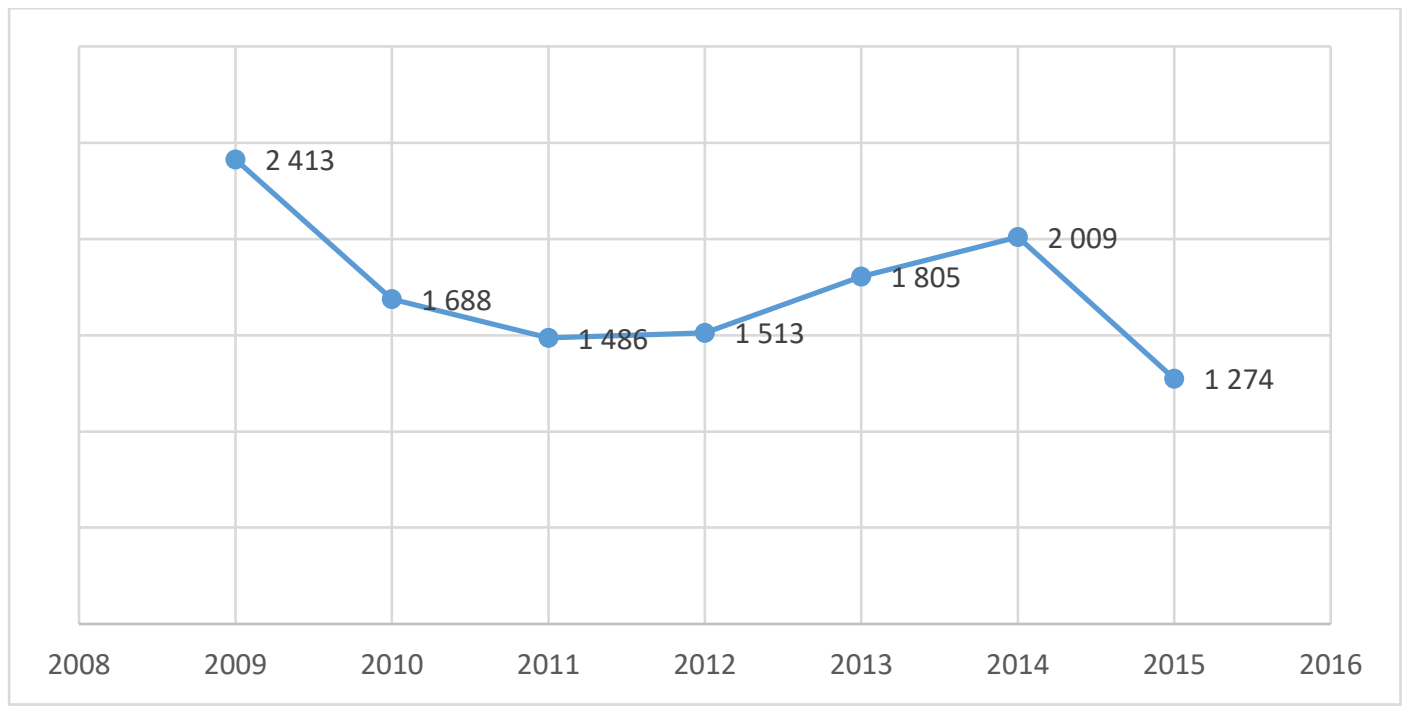

Figure 2. Jordan's foreign direct investment-billions FY 2009-2015

Source: Data adapted from the World Bank, 2017

GDP growth (annual \%). Jordan's GDP growth is at its lowest since 2005. The GDP growth is even less than Jordan's GDP growth during the global financial crisis from 2008-2010; therefore, the declining Jordan GDP growth after the Syrian refugee crisis indicates the economic impact of Syrian refugees on an already fragile economy. The governor of the Central Bank declared that the influx of Syrian refugees and the Syrian crisis negatively impacted Jordan's economic growth and hindered its GDP growth (Al-kahlidi, 2013). Figure 3 provides details regarding the declining growth of Jordan's GDP to unprecedented levels after the Syrian refugee crisis. 


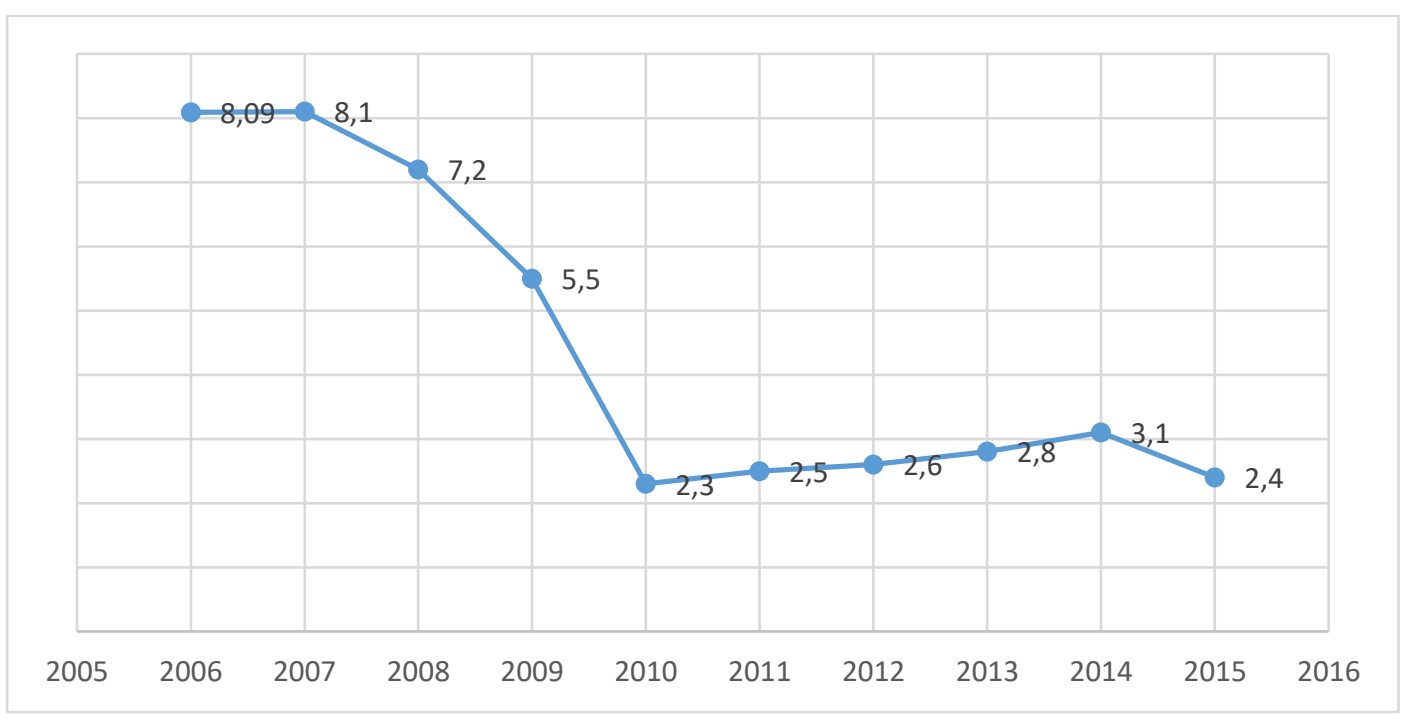

Figure 3. Jordanian annual percentage of GDP growth 2006-2015

Source: Data adapted from the World Bank

Labor market pressure. An analysis of Jordan's labor market demonstrates that Jordan's unemployment rate is high and that there is a steady increase in the female and male unemployment rates after the Syrian refugee crisis (MOPIC, 2013). However, the presence of Syrian refugees in Jordan has interior implications that affect working conditions and social cohesion (ACAPS, 2016). Considering the unemployment rate in Jordan, there is no strong evidence that Syrian refugees have impacted the unemployment rate, but this contrasts with what has been occurring in the local community. The unaffected unemployment rate is explained in two ways. First, Syrian refugees are working under unofficial and unrecorded work contracts.Second, the unemployment rate is a misleading indicator, especially in the case of hosting refugees and the local labor market because it does not reflect the number of workers who were discharged from their jobs and does not provide a number for unreported employment in the hosting community's labor market. In fact, a large panel of Jordanian women have asserted that the existence of female Syrian refugees deprived them of job opportunities in housework and knitting and sewing clothes for a modest amount of money to support their families; as a result, they became less active in their family decision making (MOPIC, 2013). Most Jordanians perceive that Syrian refugees have increased the unemployment rate and have deteriorated working conditions (ACAPS, 2016). Syrian refugees join the labor market informally, with lower wages and a lack of compliance with work condition standards that have increased the competition with Jordanians. Syrian refugees accept lower wages because they receive subsidies for food and housing from the United Nations and other humanitarian organizations. Due to the deterioration of living conditions among Jordan's middle and lower classes, Jordanians consider the humanitarian programs to be unfair in improving refugees' conditions at the expense of the host communities (Francis, 2015). The situation was worsened when the Jordanian government issued more than 22,687 free work permits to Syrian refugees in April 2016 (ACAPS, 2016). This is an alarming number that predicts the potential effects of Syrian refugees on the labor market in Jordan.

In this context, the influx of Syrian refugees into Jordan and the ramifications of the civil war in Syria have placed an extra burden on Jordan's economy. An analysis of the economic impact of Syrian refugees, through public spending, trade balance, foreign investment, GDP growth, and unemployment, provides an overall picture regarding the current economic conditions in Jordan and evidence concerning the consequences of the crisis on Jordanian host communities. Although the economic impacts of refugees vary, the adverse economic impacts of Syrian refugees on Jordan are the hallmark of the economic tier. 
Sociocultural tier. The population pressure that has resulted from the massive influx of refugees in Jordan has contributed to changes in the demographic structure of the host communities, ethnic changes, and variations in social habits and customs, which have led to social tension. This tier analyzes the effect of Syrian refugees on Jordanian host communities in the social and cultural dimensions.

Ethnic similarity.Jordanians and the Syrian refugees in Jordan share a religion, doctrine, ancestry, and language; both groups include Muslims, Sunnis, Arabs, and Arabic speakers (Haynes, 2016). Theoretically, refugees who are similar to host communities in terms of their cultural background, affiliations, and language are less likely to have negative impacts on the social structure of the host communities (UNHCR, 1997b). However, in the case of Jordan, tribal identity is an essential driver of social discrimination in society because Jordanians focus on kinship and blood and genealogical ties; therefore, Jordanian tribes are less receptive to outsiders and subcultural identities (Haynes, 2016).

Traditions and habits variation. The common cultural factors between Jordanians and Syrian refugees do not eliminate the discrepancies in habits and customs. To illustrate, Jordanians in the northern governorates exhibit resentment against Syrian refugees due to their personal practices, such as Syrian women strolling the streets late at night (MercyCorps, 2013). Moreover, Jordanians consider Syrians to be less religious and violators of Islamic principles in their conduct and speech (MercyCorps, 2013). Other habits that make Jordanians angry with refugees include their water consumption behavior. Jordanians have argued that Syrian refugees do not recognize a water shortage in Jordan and that they do not conserve water in their daily habits (BBC, 2013; MercyCorps, 2013). Syrian refugees who originally depended on the Tigris and Euphrates Rivers may not appreciate the value of each drop of water to Jordanians.

Social competition. Jordanians pay the price of the existence of Syrian refugees in their communities. Social tension has been elevated between Syrian refugees and Jordanians because they are competing for limited job opportunities, housing, and public services (Reach, 2014). As part of the social competition, Jordanian women have accused Syrian women refugees of interfering with their marriage chances because Syrian refugee families accept smaller dowries (BBC, 2014; Seeley, 2015). Jordanian men have also asserted that they have postponed getting married because of increased housing prices and the difficulty of finding an apartment to rent at a reasonable price (BBC, 2014).

Population pressure. Natural population growth coupled with population pressure due to the steep influx of Syrian refugees has created demographic changes in Jordan (Kumaraswamy \& Singh, 2016). Table 1 presents the percentage of male and female Syrian refugees compared to their Jordanian host communities. A population change entails unhealthy social practices such as underage marriage, child labor, and violations of the receiving state's social laws and regulations (Martin, 2005).

The presence of Syrian refugees in Jordanian host communities emphasizes the possible effects of the social threat of newcomers to society, even if they share major cultural pillars. Host communities cannot absorb the population pressure, different lineage, and custom variations. However, the magnitude of the sociocultural impact is increased when the refugees that come to the receiving state have a different culture, religion, and language. To summarize, Brown (1996) stated: "the sudden influx of refugees can aggregate ethnic problems and further complicate the picture by changing the domestic balance of power" (p.576).

Environmental tier. The influx of refugees affects the ecological system of a receiving state through degradation, deforestation, water consumption, and pollution (Jacobsen, 1997). The environmental tier includes the environmental factors that assess the effects of refugees on the ecology of the receiving state, particularly the effect of Syrian refugees on the Jordanian ecological system. 
The Percentage of Syrians to Jordanians in Jordan, 2015

\begin{tabular}{|c|c|c|c|}
\hline Governorates & $\begin{array}{c}\text { \% of Syrians to } \\
\text { Jordanians }\end{array}$ & $\begin{array}{c}\text { \% Syrian males to } \\
\text { Jordan males }\end{array}$ & $\begin{array}{c}\text { \% Syrian females to } \\
\text { Jordanian females }\end{array}$ \\
\hline Irbid & 19.4 & 18.2 & 20.67 \\
\hline Mafraq & 37.8 & 36 & 4.96 \\
\hline Jerash & 4.5 & 7.3 & 8.55 \\
\hline Ajloun & 8.2 & 10.2 & 11.58 \\
\hline Amman & 10.8 & 5.3 & 6.1 \\
\hline Albalqa & 5.7 & 12 & 8.1 \\
\hline Zarqa & 12.8 & 7.4 & 5.5 \\
\hline Madaba & 7.7 & 5.2 & 6 \\
\hline Kerak & 5.4 & 5.7 & 2 \\
\hline Maan & 5.8 & 2 & 4.5 \\
\hline Tafilaha & 2 & 3.8 & 9.25 \\
\hline Aqaba & 4.1 & 12.6 & 13.7 \\
\hline Total & 13.27 & & \\
\hline
\end{tabular}

Note. Data adapted from Department of Statistics, Jordan (2016).

Water consumption. Jordan is the fourth poorest country in the world in terms of water resources. With the presence of Syrian refugees, Jordan's water shortage has increased, and the discrepancy between the available water sources and demand has been notable (UNHCR, 2013b). The northern governorates have experienced an increase in water shortages due to their receiving 70\% of the Syrian refugees (UNHCR, $2013 \mathrm{~b})$. The increased demand for water reduces the amount and frequency of the water supply. Evidently, water resources are exhausted more than twice per month in rural and urban areas and are 44\% and 33\%, respectively (UNHCR, 2013b). The Jordanian Ministry of Planning and International Cooperation assessed the degree of pressure on the water supply after the arrival of Syrian refugees and found that $70 \%$ of Jordanians and Syrian refugees are receiving less than the national standards, which is 100 liters per person per day (MOPIC, 2015b). Sixty-two percent of the total water vulnerability index was attributed to the presence of Syrian refugees (MOPIC, 2015b).An enormous number of Syrian refugees in the northern governorates significantly increased the pressure on sewage systems in local government and refugee camp management (UNHCR, 2013b).

Land degradation and ecosystem violation. The increasing population, poverty, and deterioration of economic conditions of Jordanians due the influx of Syrian refugees has caused Jordanians to utilize natural resources, such as illegally cutting trees or overgrazing, to compensate for the high prices of fuel and petroleum by increasing the supply (MOPIC, 2015b). Evidently, the number of environmental violations increased after the influx of Syrian refugees. Table 2 presents the numbers of environmental violation cases and the type of violation. 
Environmental Violations in 2014

\begin{tabular}{|c|c|}
\hline Environmental violation & Number of court cases \\
\hline Illegal wood cutting & 572 \\
\hline Illegal grazing & 75 \\
\hline Illegal hunting & 84 \\
\hline Forest fires & 25 \\
\hline Wildlife violation & 727 \\
\hline
\end{tabular}

Notes. Data adapted from the Ministry of Planning and International Cooperation, JRP 2015 (MOPIC, 2015a).

Energy. Jordan suffers from a scarcity of energy resources, and it imports $97 \%$ of its energy requirements (MOPIC, 2015b). The consumption of residential electricity increased by 1,634 Gigawatts from 2009 to 2014. The consumption of light petroleum gas increased by 336,000 tons (MOPIC, 2015b).

Air pollution. The increase of population pressures due to the influx of Syrian refugees and the reliance of Jordan on fuel oil and highly sulfuric products has led to an increase in air pollution. The enormous number of Syrian refugees in Jordan has created pressure on the transportation system and an increase in the number of vehicles on the road, which concomitantly increases the emission of air pollutants (MOPIC, 2015b).

Medical waste. The surge of Syrian refugees and their pressures on the healthcare sector create an increase of medical and bio-hazardous waste. For example, since the Syrian refugee crisis, medical waste increased 213,283 tons per year, and pharmaceutical waste increased 1,127 cubic meters per year (MOPIC, 2015b).

The environmental impact of Syrian refugees was manifold because Jordan is already subject to scarce natural resource threats due to water shortage, desertification, and a lack of energy resources. The population pressure that has been created by the influx of Syrian refugees has intensified the situation and caused the Jordan government to exert more efforts to protect its ecosystem and generate alternative renewable energy sources to alleviate the environmental impact and reduce the potential social tension between the refugees and host communities. Table 3 presents the estimated costs of both responding to the environmental threats from the influx of Syrian refugees and providing sustainable solutions for both the refugees and host communities.

Table 4

The Estimated Budget Requirements from 2014-2018 (USD)

\begin{tabular}{|c|c|c|c|c|c|}
\hline $\begin{array}{c}\text { Environmental } \\
\text { factor }\end{array}$ & $\mathbf{2 0 1 4}$ & $\mathbf{2 0 1 5}$ & $\mathbf{2 0 1 6}$ & $\mathbf{2 0 1 7}$ & $\mathbf{2 0 1 8}$ \\
\hline $\begin{array}{c}\text { Ecosystem } \\
\text { preservation }\end{array}$ & $\mathrm{N} / \mathrm{A}$ & $7,300,000$ & $1,650,000$ & $1,800,000$ & 300,000 \\
\hline Water \& sanitation & $158,793,612$ & $87,390,000$ & $238,800,000$ & $263,520,000$ & $246,560,000$ \\
\hline Energy & $\mathrm{N} / \mathrm{A}$ & $134,006,100$ & $107,400,000$ & $111,075,000$ & $87,000,000$ \\
\hline
\end{tabular}

Notes. Data adapted from the Ministry of Planning and International Cooperation, JRP2014, 2015and JRP 2016-2018 (MOPIC, 2014; MOPIC, 2015a). 


\section{POLICY RECOMMENDATION}

The comprehensive analytical framework of refugee adoption implied that the presence of Syrian refugees in Jordan strains Jordan and Jordanian host communities. The overall analysis of this crisis postulated that the competition between refugees and host communities over scarce resources and the population pressure due to the influx of refugees on public goods and services have increased the burden on the government. Jordan's government is burdened with the unexpected population pressure and the exponential increase of demand on public goods and services. Jordan must improve its intersectoral relations. Therefore, we suggests that public-private partnerships would assist Jordan's government in reducing its strain and help the vulnerable society recover from the sudden fluctuations that have accompanied the influx of Syrian refugees. In essence, partnership with the private sector entails a collaborative relationship between public and private organizations, which would unite resources to identify a problem and to follow a joint strategy to solve it (Kapucu, 2006). Partnership between the private sector and nonprofit organizations is considered an effective way to deal with the crisis (Kapucu, 2006). A parallel argument is that complex problems and disorder conditions require convoluted solutions in the form of bilateral agency plans (Ackoff, 1974; Kapucu, 2006). Scholars have argued that networking and partnerships are pivotal solutions to complex and global problems (Ostrom, 1990). Public-private partnerships integrate parties' resources, power, and strategies to formulate a coherent resilient response; therefore, the intervention of the Jordanian private sector as a strategic partner to alleviate the ramifications of Syrian refugees will improve the competency of the solutions and unify the relationship between Jordanian community layers.

Moreover, we recommend that the Jordanian government develop a partnership with Jordanian communities to assist in reducing the pressure on the government and to help Syrian refugees. In other words, social capital should be used as part of the response to the Syrian refugee crisis. Social capital is defined as "sum up a society's capacity for self-organization- its capacity to promote and coordinate efforts for collective action" (Kapucu, 2006, p. 209). The particularity of this maneuver is that the amalgamation of private social infrastructure with public plans to improve the community structure of social capital preserves resources, involves relations with several actors, and employs communication channels to exchange information and to exercise collective action (Kapucu, 2006). Wildavsky (1971) considered that the resilience of a society and its ability to deal with sudden threats depends on its preparedness and understanding of the situation. In essence, social capital helps in providing public education, ensuring continuation of the smooth performance of government organizations, and preventing criminal acts through informal controlling (Kapucu, 2006). In reality, Jordanian society is able to assist the government in providing social services, maintaining safety and security, and showing more understanding and safeguarding of refugees to facilitate government treatment of the Syrian refugee crisis.

The analytical framework demonstrated that there is a tension between Syrian refugees and Jordanians as host communities due to the competition over limited resources and job opportunities, variations in habits and customs, deterioration of living conditions, and the political conflict of the Jordanian government with the sending state. For this reason, it is important to co-opt this resentment and anxiety to avoid more bickering and any possible tension escalation. We suggest that the tension between Syrian refugees and Jordanians can be abated through believing in the participative ideology and applying communitarianism concepts to absorb the current tension between refugees and host communities. Peters (1995) assumed that lower level actors and increased public participation confirm better communication and information exchange and contribute to coordination and responsiveness of policies. In the same vein, community involvement in a policy strengthens the political process (Etzioni, 1993). Etzioni (1993) promoted the necessity of collaboration between communities and the nation to accomplish both individual needs and 
societal goals. This leads the discussion to the role of bottom-up practices of host communities in responding to the refugee crisis. GCSP and IOM (2015) asserted that bottom-up approach actors representing citizens is a key issue in refugees' dilemma. This can occur by citizens understanding the aspects of the problem and engaging in effective communication with the government and refugees (GCSP \& IOM, 2015). To put this into context, the empowerment of Jordanians to be part of the solution to the Syrian refugee crisis is a technique to reduce the tension and make Jordanians more understanding of the crisis and its ramifications. Also, open communication channels and the sense of responsibility adjust the disagreement between Syrian refugees and Jordanians and reduce the gap between both parties in a way that removes the anxiety and tension and promotes stability.

Overall, the presence of refugees in a receiving state is a complex issue, and there is no optimal remedy to tackle this problem and keep the balance between citizens' needs and refugees' needs, between protection and security, and between solidarity and hospitality. However, partnership, social capital, a participatory approach, and communitarianism are considered important strategies to reduce the burden on the government and improve social services and to relieve the anxiety and tension of refugees and citizens.

\section{CONCLUSION}

In conclusion, a comprehensive analytical framework for refugees' adoption in the receiving state has been constructed as an assessment tool to investigate the impact of refugees on a receiving state and the changes that occur with their arrival based on contextual factors. The absence of a wide-ranging theory that answers a specific question regarding the impact of refugees' influx on a receiving state and host communities has led to the development of this analytical framework to assist researchers and policymakers in evaluating the overall impact of the acceptance of refugees based on strict scientific principles and measurable factors that can be tested through sub-models and descriptive statistics.

The comprehensiveness, flexibility, and multiple disciplines of this framework make it applicable to different countries, for various refugee cases and multiple users from different academic fields concerning the geopolitical variations of countries, cultural structures, economic power, and environmental position. Although this framework is not aligned with a particular theory, it clarifies and explains the changes that have accompanied the influx of refugees.

This analytical framework illustrates the impact of Syrian refugees on Jordan based on the political, economic, sociocultural, and environmental tiers. This framework has demonstrated the repercussions of Syrian refugees' presence on the Jordanian government and host communities. This framework illustrates Jordan's political response to this crisis considering the massive threats caused by the political tension with the sending the state and the fighting of terrorism and Jordan's provision of humanitarian assistance to Syrian refugees. Moreover, Syrian refugees have negatively impacted the Jordanian economy and labor market, except for the slight increase in the investment indicator. The shared religion and language have been insufficient to ensure social cohesion between Syrian refugees and Jordanians, and social tension has been notable due to the tribal identity variation, dissimilarity in habits and customs, and competition for limited resources and public services. Water shortages, energy resource scarcity, land use, and pollution were intensified after the Syrian refugee influx.

Finally, an analysis of the impact of refugees in the receiving state is inseparable, and a classification in terms these factors to organize and categorize this impact facilitates generalization of the analysis results. This discussion shows that economic impacts lead to social tensions or political intervention and that economic deterioration can indirectly impact the ecosystem and natural resources in addition to creating social tension. 


\section{REFERENCES}

Abuqudairi, A. (2014, May 26). Jordan expels Syrian ambassador for "insults." [Press release]. Retrieved from http://www.aljazeera.com/news/middleeast/2014/05/jordan-expels-offensive-syrian-ambassador201452612936528650.html.

ACAP: The Assessment capacity project. (2016, August 24). Syrian refugees: Political and financial dynamic. Thematic report. Retrieved from http://www.alnap.org/resource/23262.

Achilli, L. (2015, February). Syrian refugees in Jordan: A reality check. Migration Policy Center. doi:10.2870/821248.

Ackoff, R. L. (1974). Redesigning the future: A systems approach to societal problems. New York, NY: Wiley.

Adleman, H. (1998). Why refugee warriors are threats. Journal of Conflict Studies, 18(1), 49-69.

Aljazeera. (2015, October 14). Jordan and Russia to cooperate on Syria military action [Press release]. Retrieved from https://www.aljazeera.com/news/2015/10/jordan-russia-cooperate-syria-military-action151024074311276. html.

Aljazeera, News (2017, January 21). Deadly bomb blast bits Rakban refugee camp near Jordan. Retrieved from http://www.aljazeera.com/news/2017/01/deadly-bomb-blast-hits-Syria-rakban-refugee-camp170121130211057.html.

Al-Khalidi, S. (2013, October 29).Jordan's economic growth hit by Syrian refugee burden: Central Bank. Reuters [press released]. Retrieved from https://www.reuters.com/article/us-meast-investment-jordan/jordans-economic-growth-hitby-syrian-refugee-burden-central-bank-idUSBRE99S0PN20131029.

Allport, G. W. (1954). The nature of prejudice. Cambridge, MA: Addison-Wesley.

Arab News (2014, April 17).Vebicles bit in Jordan air raid, not Syria Army's. [Press release]. Retrieved from http://www.arabnews.com/news/556801.

Baez, J. E. (2011). Civil wars beyond their borders: The human capital and health consequences of hosting refugees. Journal of Development Economics, 96(2),391-408. doi:10.1016/j.jdeveco.2010.08.011.

Barton, J., \& Haslett, T. (2007). Analysis, synthesis, systems thinking and the scientific method: Rediscovering the importance of open systems. Systems Research and Behavioral Science, 24, 143-155.

Baumol, W. (1952). Welfare economics and the theory of the state. Cambridge, MA: Harvard University Press.

BBC, News (2013, August 24). Viewpoints: The impact of Syrian refugees on host countries. [Press release]. Retrieved from http://www.bbc.com/news/world-23813975.

BBC, News (2014, April 6). Deadly clashes in Jordan's Zaatari camp. Retrieved from http://www.bbc.com/news/worldmiddle-east-26908587.

BBC, News (2015, February 3). Profile: IS-beld Jordanian pilot Moaz al-Kasasbeh [Press release]. Retrieved from http://www.bbc.com/news/world-middle-east-31021927.

Berry, L. (2008). The impact of environmental degradation on refugee-host relations: A case study from Tanzania (Research Paper No. 151). The United Nation Refugee Agency.

Betts, A. (2009). Development assistance and refugees, towards a north-south grand bargain? Forced migration policy briefing. Refugee Studies Centre, University of Oxford, United Kingdom.

Beissinger, M. R. (2002). Nationalist mobilization and the collapse of the Soviet state. Cambridge, UK: Cambridge University Press.

Brown, M. E. (1996). The international dimensions of internal conflict. Cambridge, MA: The MIT Press.

Carey, G., Malbon, E., Carey, N., Joyce, A., Crammond, B., \& Carey, A. (2015). BMJ open system science and systems thinking for public health: A systematic review of the field. BMJ., 1-9.

Central Bank of Jordan. (2017). Retrieved from http://statisticaldb.cbj.gov.jo/index?lang=en.

Clarke, K. (2016, Summer). The politics of refugees' relief. Retrieved from https://www.dissentmagazine.org/article/politics-refugee-relief-zaatari-camp-humanitarian-crisis.

Darnhofer, I. G., Gibbon, D., \& Dedieu, B. (2012). Farming systems research: An approach to inquiry. In Farming systems approach into the 21st century: The new dynamic (pp. 3-31). Dordrecht, Netherland: Springer Science and Business Media.

Davis, D. R., \& Moore, W. H. (1998). Ethnicity matters: Transnational ethnic alliances and foreign policy behavior. International Studies Quarterly, 41(1), 171-184. doi:10.1111/0020-8833.00037. 
De Groot, O. (2010). The spill over effects of conflict on economic growth in neighboring countries in Africa. Defence and Peace Economics, 21(2), 149-164.

Deppler, M. C., \& Kincaid, R. (1999). The economic consequences of the Kosovo Crisis: An updated assessment. International Monetary Fund.

Dixon -Wood, M., Agarwal, S., \& Jones, D. (2005). Synthesising qualitative and quantitative evidence: A review of possible methods. Journal of Health Services Research and Policy, 10, 45-53.

Edwards, V. M., \& Steins, N. A. (1998). Developing an analytical framework for multiple-use commons. Journal of Theoretical Politics, 10(3), 347-383.doi:10.1177/0951692898010003008.

Etzioni, A. (1993). The spirit of community. New York, NY: Crown Publishers.

Franek, F. (2016, November 20). Foreign debt on the rise. The Jordan Times.Retrieved from http:/ / www.jordantimes.com/opinion/fahed-fanek/foreign-debt-rise.

Francis, A. (2015, September 21). Jordan's refugee crisis. Carnegie Endowment for International Peace, 12. Retrieved from http://carnegieendowment.org/2015/09/21/jordan-s-refugee-crisis-pub-61338.

GCSP. (2015, Nov. 2). Refugee crisis: National and buman security implications. Public discussion. Retrieved from https://www.gcsp.ch/Events/Refugee-Crisis-National-and-Human-Security-Implications.

Gomez, M. P., \& Christensen, A. (2011). The impacts of refugees on neighboring countries: A development challenge. The World Development - World Bank.

Griffiths, M., \& Kickul, J. (2013, March/April). "The tragedy of the commons" social responsibility: Opportunities but still obstacles for social entrepreneurs. Ivey Business Journal.

Hackl, A. (2013, November 1). Politics and power in Jordan's Za'atri refugee camps. IRIN NEWS. Retrieved from phttp://www.irinnews.org/analysis/2013/11/01/politics-and-power-jordan's-Zaatari-refugee-cam.

Haider, H. (2014). Refugee, ID and host community radicalization. GSDRC Applied knowledge services, Helpdesk research report.

Haynes, W. (2016). Jordanian society's responses to Syrian refugees. Military Review. Retrieved from http://usacac.army.mil/CAC2/MilitaryReview/Archives/English/MilitaryReview 20160228 art011.pdf.

Jacobsen, K. (1997). Refugees' environmental impact: The effect of patterns of settlement. Journal of Refugee Studies, 10(1), 19-36.doi:10.1093/jrs/10.1.19.

Jordan Department of Statistics (2016). Number of Syrian refugees in Jordan by Governorates Jordan Times. (2017, March 27). Border guards kill 2 suspected drug smugglers. Retrieved from http://jordantimes.com/news/local/borderguards-kill-2-suspected-drug-smugglers.

Kapucu, N. (2006). Public non-profit partnerships for collective action in dynamic contexts of emergencies. Public Administration, 84(1), 205-220.

Kirui, P., \& Mwaruvie, J. (2012). The dilemma of hosting refugees: A focus on the insecurity in northeastern Kenya. International Journal of Business and Social Science, 3(8).

Kumaraswamy, P. R., \& Singh, M. (2016). Population pressure in Jordan and the role of Syrian refugees.Migration and Development.Retrieved

from http://www.tandfonline.com/doi/abs/10.1080/21632324.2016.1141500?journalCode=rmad20.

Lichtenstein, A. H., Yetley, E. A., \& Lau, J. (2009). Application of systematic review methodology to the field of nutrition: Nutritional research. Agency for Healthcare Research and Quality (US), 38(12), 2297-2306.doi: 10.3945/jn.108.097154.

Lozi, B. M. (2013). The effect of refugees on host country economy: Evidence from Jordan. Interdisciplinary Journal of Contemporary Research Business, 5(3), 114-126.

Luck, T. (2016, May 24). Jordan's Syria refugee economic gamble. Middle East Institute. Retrieved from http://www.mei.edu/content/article/jordan-s-syrian-refugee-economic-gamble.

Martin, A. (2005). The environmental conflict between refugee and host communities. Journal of Peace Research, 42(3), 329-346.

Maystadt, J., \& Verwimp, P. (2014). Winners and losers among a refugee-hosting population. Economic Development and Cultural Change, 62(4), 769-809. doi:10.1086/676458.

McGinnis \& Ostrom, E. (2014). Social-ecological system framework: Initial changes and continuing challenges. Ecology and Society, 19(2), 30-42. 
MercyCorps. (2013). Mapping of host community - refugee tensions in Mafraq and Ramtha, Jordan. United Nations Refugees agency.

Meyers, N. (1997, November). Environmental refugees. Population and Environment, 19(2nd ser.), 167-182.

MOPIC. (2013). Needs assessment review of the impact of the Syrian crisis on Jordan. Amman, Jordan: The Ministry of Planning and International Cooperation.

MOPIC. (2014, December 17). Jordan response plan 2015 for the Syria crisis. Amman, Jordan: The Ministry of Planning and International Cooperation.

MOPIC. (2015a). Jordan response plan for Syrian crisis 2016-2018. Amman, Jordan: The Ministry of Planning and International Cooperation.

MOPIC. (2015b). Comprehensive vulnerability assessment. Amman, Jordan: The Ministry of Planning and International Cooperation.

Morris, T. (2010). Urban refugees in Yemen. Forced Migration Review, 34, 36-37.

Murdoch, J. C., \& Sandler, T. (2004). Civil wars and economic growth: Spatial dispersion. American Journal of Political Science, 48(1), 138-157. doi:10.2307/1519902.

Nasser, R., \& Symansky, S. (2014, January 5). The fiscal impact of the refugee crisis on Jordan. Washington, DC: The United States Agency for International Development.

Ostrom, E. (1990).Governing the Commons: The evolution of institutions for collective action. Cambridge, UK: Cambridge University Press.

Ostrom, E. (2005).Understanding institutional diversity. Princeton, NJ: Princeton University Press.

Ostrom, E. (2009).A general framework for analyzing the sustainability of social-ecological systems.Science, 325, 419422.

Peters, G. (1995). The politics of bureaucracy: An introduction to Compare Public Administration. New York, NY: Routledge.

Pini, J. (2008). ). Political violence and the African refugee experience. International Affairs Review. Retrieved from http://www.iar-gwu.org/node/19.

Kirui, P., \& Mwaruvie, J. (2012). The dilemma of hosting refugees: A focus on the insecurity in northeastern Kenya. International Journal of Business and Social Science, 3(8).

Reach. (2014). Evaluating the effect of the Syrian refugee's crisis on stability and residence in Jordanian host communities. Retrieved from http://www.reach-initiative.org/reach-evaluates-the-effect-of-the-syrian-refugee-crisis-on-stability-andresilience-in-jordanian-host-communities-preliminary-impact-assessment.

Richmond, B. (1993). Systems thinking: Critical thinking skills for the 1990s and beyond. System Dynamics Review, 9(2), 113-133.

Ritchey, T. (1991). On scientific method - Based on a study of Bernhard Riemann. Systems Research, 8(4), 21-41.

RT NEWS, Report. (2012, August 10). Syrian and Jordanian troops clash at the border - report [Press release]. Retrieved from https://www.rt.com/news/syria-jordan-border-clash-401/.

Saideman, S. M. (2001). The ties that divide: Ethnic politics, foreign policy, and international conflict. New York, NY: Columbia University Press.

Saif, I., \& Debartolo, D. (2007). The Iraq war's impact on growth and inflation in Jordan. Center for Strategic Studies, University of Jordan.

Salehyan, I. (2008). The externalities of civil strife: Refugees as a source of international conflict. American Journal of Political Science, 52(4), 787-801. doi:10.1111/j.1540-5907.2008.00343.x.

Salehyan, I., \& Gleditsch, K. S. (2006). Refugees and the spread of civil war. International Organization, 60(02), 335-366. doi:10.1017/s0020818306060103.

Schenker, D. (2017). The growing Islamic state threat in Jordan. The Washington Institute for near east policy. Policy Watch 2747.

Seeley, M. (2015). Jordanian hosts and Syrian refugees: Comparing perceptions of social conflict and cohesion in three host communities. Generations of Peace Institute Research, 4-104.

Sharp, J. (2016, January 27).Jordan: Background and U.S. relations. Washington, DC: Congressional Research Service.

Sharp, J. (2017, January 25).Jordan: Background and U.S. relations. Washington, DC: Congressional Research Service. Middle East Affairs.The U.S. Congress. 
Stanley, L. (2012). The difference between an analytical framework and a theoretical claim: A reply to Martin Carstensen. Political Studies, 60(2), 474-482.doi:10.1111/j.1467-9248.2012.00960.x.

Taha, K. (2015, April 26). Jordan's most important trade route has been cut after the Syrian border closure. Business Insider. Retrieved from http://www.businessinsider.com/afp-key-jordan-trade-route-cut-after-syria-borderclosure-2015-4.

Trading Economics (2017). Jordan government debt to GDP 2007-2015. Retrieved from http://www.tradingeconomics.com/jordan/government-debt-to-gdp.

UN High Commissioner for Refugees. (1997b, January 6).Social and economic impact of large refugee populations on host developing countries. Report: Executive Committee of the High Commissioner's Programme Standing Committee.

UN High Commissioner for Refugees. (2007). Note on the integration of refugees in the European Union. Retrieved From http://www.unhcr.org/463b462c4.pdf.

UN High Commissioner for Refugees. (2013b). Syria regional refugee response. Retrieved from http://data.unhcr.org/syrianrefugees/regional.php.

UN High Commissioner for Refugees. (2013c). Zaatri governance plan. Retrieved from https://reliefweb.int/report/jordan/zaatari-governance-plan-june-2013.

UN High Commissioner for Refugees. (2015). Refugees/migrants emergency response -Mediterranean.Retrieved from http://data.unhcr.org/mediterranean/regional.php.

UNOCHA. (2016). The Syrian Arab Republic. Retrieved from http://www.unocha.org/syrian-arab-republic/syriacountry-profile/about-crisis.

Weiner, M. (1993). Security, stability, and international migration. International Security,17(3), 91-126. doi: $10.2307 / 2539131$

Whitaker, B. E. (2002). Refugees in western Tanzania: The distribution of burdens and benefits among local hosts. Journal of Refugee Studies, 15(4), 339-358. doi:10.1093/jrs/15.4.339.

Wildavsky, A. (1971). Searching for safety. New Brunswick, NJ: Transaction.

Women's Refugee Commission. (2009). Peril or protection: The link between livelihoods and gender-based violence in displacement settings. New York, NY: Author.

World Bank (2017).Jordan's foreign direct investment-billions FY 2009-2015. Retrieved from http:/ / data.worldbank.org/indicator/BX.KLT.DINV.CD.WD?end=2015\&locations=JO\&start=1999.

World Bank (2017).Jordanian Annual percentage of GDP growth 2006-2015. Retrieved From .

https:/ / data.worldbank.org/indicator/NY.GDP.MKTP.KD.ZG?end=2015\&locations=JO\&start=1994.

Zetter, R. (2015). Are refugees an economic burden or benefit? Refugee Studies Centre, 41, 50-52. 